\title{
ATTITUDE TOWARD LEISURE AMONG THE COMMUNITY-DWELLING ELDERLY: AN INTERFACE FOR HEALTH PROMOTION ${ }^{1}$
}

\author{
Roberta Fernanda Rogonni Ferrari², Vanessa Denardi Antoniassi Baldissera ${ }^{3}$, Celmira Lange ${ }^{4}$, Lígia Carreira ${ }^{5}$, \\ Eraldo Schunk Silva ${ }^{6}$
}

${ }^{1}$ Article extracted from the thesis - Attitude toward leisure in the elderly community, presented in the Nursing Post Graduation course, Universidade Estadual de Maringá (UEM), 2014.

${ }^{2}$ M.Sc. in Nursing. Professor, Department of Nursing, Universidade Paranaense. Umuarama, Paraná, Brazil. E-mail: betaferrari16@ hotmail.com

${ }^{3}$ Ph.D. in Psychiatric Nursing. Professor, Department of Nursing and Post Graduation in Nursing, UEM. Maringá, Paraná, Brazil. E-mail:vanessadenardi@hotmail.com

${ }^{4}$ Ph.D. in Fundamental Nursing. Professor, School of Nursing, Universidade Federal de Pelotas. Pelotas, Rio Grande do Sul, Brazil. E-mail: celmira_lange@terra.com.br

${ }^{5}$ Ph.D. in Fundamental Nursing. Professor, School of Nursing, UEM. Maringá, Paraná, Brazil. E-mail: ligiacarreira@hotmail.com ${ }^{6}$ Ph.D. in Agronomy. Professor, Department of Bioestatistics, UEM. Maringá, Paraná, Brazil. E-mail: eraldoschunk@gmail.com

\begin{abstract}
A cross-sectional study with quantitative approach carried out with 387 community-dwelling elderly to identify their attitudes toward leisure activities in the cognitive, affective and behavioral dimensions. Data were analyzed using descriptive statistics, Fisher's association test and Spearman's correlation. Most participants were female, aged up to 80 years, married and had up to four years of schooling. The elderly had a predominantly positive attitude toward leisure in the three subscales, with a lower mean for the behavioral subscales, which indicated that some elders had a negative attitude. This was significantly associated with age, educational attainment, smoking status and functional capacity. In conclusion, a positive attitude and greater involvement in leisure activities allows health professionals to raise a critical reflection in the elderly, especially in their behavioral attitude to rethink the planning, opportunities and resources for leisure.
\end{abstract}

DESCRIPTORS: Health of the elderly. Attitude. Leisure activities. Geriatric nursing. Aged.

\section{ATITUDE DO IDOSO DA COMUNIDADE FRENTE AO LAZER: UMA INTERFACE COM A PROMOÇÃO DA SAÚDE}

\begin{abstract}
RESUMO: Estudo descritivo, transversal, de abordagem, quantitativa realizado com 387 idosos na comunidade com objetivo de identificar as atitudes dos idosos frente às atividades de lazer nas dimensões cognitiva, afetiva e comportamental. Os dados foram analisados por estatística descritiva, teste de associação (Fisher) e correlação de Spearman. Predominaram mulheres até 80 anos, casados(as), até quatro anos de escolaridade, representando a maioria do estudo. Obteve-se predominantemente atitude positiva dos idosos frente ao lazer nas três subescalas, apresentando média mais baixa na comportamental, evidenciando atitude negativa em alguns idosos, o qual apresentou associação significativa com a faixa etária, escolaridade, hábito tabagista e capacidade funcional. Conclui-se que a atitude positiva e maior envolvimento nas atividades de lazer permite aos profissionais de saúde suscitar no idoso uma reflexão crítica, principalmente na atitude comportamental ao repensar o planejamento, oportunidades e recursos para a realização do lazer.
\end{abstract}

DESCRITORES: Saúde do idoso. Atitude. Atividades de lazer. Enfermagem geriátrica. Idoso.

\section{ACTITUD DEL ANCIANO EN LA COMUNIDAD DE FRENTE AL OCIO: APORTES PARA LA ATENCIÓN DE ENFERMERÍA}

\begin{abstract}
RESUMEN: Estudio transversal con enfoque cuantitativo realizado entre 387 adultos mayores en la comunidad con el fin de identificar las actitudes de los adultos mayores de frente a las actividades de ocio en las dimensiones cognitivas, afectivas y conductuales. Los datos se analizaron mediante estadística descriptiva, prueba de asociación (Fisher) y la correlación de Spearman. La mayoría de los participantes eran mujeres, de hasta 80 años de edad, casado(a) y que poseían hasta cuatro años de escolaridad. Se obtuvo la actitud predominantemente positiva de pacientes de edad avanzada de frente al ocio en las tres sub-escalas, presentando la media más baja en la escala comportamental, evidenciando actitud negativa en algunos adultos mayores, lo cual presentó asociación significativa con la edad, el nivel educativo, el tabaquismo y la capacidad funcional. En conclusión, la actitud positiva y la mayor participación en las actividades de ocio permite a los profesionales de salud que plantean una reflexión crítica, principalmente la actitud comportamental al repensar la planificación, las oportunidades y los recursos para la realización de actividades de ocio.
\end{abstract}

DESCRIPTORES: Salud del anciano. Actitud. Actividades de ocio. Enfermería geriátrica. Anciano. 


\section{INTRODUCTION}

The production of knowledge of leisure is recent in Brazil. Leisure is related to human emancipation, is a strategy for health promotion, and has motivated investigation by professionals in several fields and contexts. The first discussions considered leisure a set of occupations the individual could do at his own free will, to rest or have fun. ${ }^{1}$ In addition to contributing to resting and enjoyment, leisure educates and liberates by creating subsidies for social and personal development and is related to a positive self-perception of health. ${ }^{2}$

Another aspect of leisure is the concrete possibility to develop emancipatory leisure, by breaking economic, social and political barriers in the search for some time to practice freedom, autonomy and transformation. ${ }^{3}$

Contributions originating from the practice of leisure are extremely relevant in the context of the population's ageing, for it offers positive benefits to the senior citizen's health by implementing health promotion programs. The fact that the elderly maintain a healthy lifestyle for longer offers conditions for active ageing with positive results to the whole of society. ${ }^{4}$

An individual's involvement with leisure is determined by his attitudes, which are associated to the way in which he tries and experiences leisure activities. ${ }^{3}$ Learning the individual attitudes makes it possible to interfere and stimulate more positive attitudes toward leisure. This raises the level of the social, physical and psychological well-being of both the individual and the collectivity: a greater willingness to perform different leisure activities can be linked to positive attitudes. ${ }^{5}$

Among the different concepts of attitude, the one better associated toward leisure can be operated in a comprehensive and appropriate manner when it involves the separate investigation of the three components of attitude (cognitive, affective and behavioral). The cognitive component pertains to the individual's knowledge, opinions and beliefs; the affective component pertains to feelings and manifests the intensity of enjoyment in becoming involved in leisure activities or not; and the behavioral component shows past leisure experiences, which generate future motivation for greater involvement in leisure activities if they were positive. ${ }^{5}$

Old age becomes a conquest of experiences; however, it brings concurrent challenges to overcome. Living this stage of life productively and satisfactorily in such a manner that positive feelings such as pleasure are generated has great impact on senior citizens' lives. Health is promoted when the elderly become more active, feel less frustrated and incapable and have more quality of life. ${ }^{6}$

The idea of health maintenance has turned leisure into more than a basic human need: it has become a constitutional right. Leisure shows that the elderly have emancipatory potential in the search for new experiences, values, attitudes and meanings to their lives, with the consequent greater socialization and satisfaction with life. It is thus an essential factor to stimulate creativity and conquer well-being and health.

Senior citizens who have lived difficult lives, worked a lot and suffered deprivation can find it difficult to acquire new habits, a negative aspect in their attitudes toward leisure that affects healthy ageing. Showing the transformative role of leisure to senior citizens is essential for them to enjoy a more relaxed life and socialize more. ${ }^{7}$

Professional nurses should stimulate and offer community-dwelling senior citizens the correct focus for their better involvement in leisure activities. They should pay attention to the particularities of their personal history, which can positively or negatively influence this experience, so that the benefits of leisure can be reached in a relaxed, pleasant and creative manner.

The study of leisure is extremely relevant to understand the process of differentiation among the several groups that compose society, especially the community-dwelling elderly. Since they have different conditions and perceptions, they show a potential for change that can suffer effective interventions when they adopt a more positive attitude, which is an efficient tool to promote health, adopt healthy lifestyles and base nursing practices.

Within this context, the question to be asked is the following: what is the attitude of the communitydwelling elderly toward leisure activities in a small municipality? The objective of this study was to identify the attitudes of the community-dwelling elderly toward leisure in a small municipality in the northwestern region of Paraná, Brazil, and to classify it in the cognitive, affective and behavioral dimensions.

\section{METHOD}

This is a descriptive, cross-sectional and quantitative study performed in a small municipality in the Northwestern region of the state of Paraná, Brazil. The target population was formed by 609 
individuals aged 60 years or older, registered with the Basic Care Information System (SIAB, Sistema de Informação da Atenção Básica).

Study participants were elderly people who met the following criteria: aged 60 years or older; resident in the urban area of the municipality; registered with the SIAB through Form A and agreed to participate in the study. The exclusion criteria were the participant's absence from home after three attempted visits, or death, travelling, change of address, refusal to participate in the study, work and not having cognitive ability to respond the study questions in the Mini-Mental State Examination (MMSE).

A total of 45 senior citizens could not participate in the study for not meeting the established criteria. Three of them changed address, eight died during the study period, 14 did not reach the minimum MMSE score, five did not accept to participate in the study and 15 were not found after three attempted home visits.

After data collection had been concluded, the replacement strata were used to perform a new draw for the exclusions, according to the number of losses in the first stage. In the second data collection stage, there was no losses and the process was concluded.

The sample size (387 senior citizens) was calculated applying the rule of sample proportions, using the correction factor for finite populations.

A 5\% significance level was adopted, with $3 \%$ error and $p=0.5$. Stratification by sex and age group was used to select the sample. The sample in each stratum was directly proportional to this stratum size.

Data were collected from December 2013 to March 2014 at the senior citizens' homes, in a private place where other residents did not interfere. The visit was scheduled over the phone, according to the interviewee's and the investigator's availability. The objectives were presented and the participants who agreed to participate in the study signed the Informed Consent Form for the subsequent application of the instruments.

A structured script formed by three instruments was used during the interview. The first instrument characterized the sociodemographic profile of the elders (sex, age, education, marital status, work ties and family income) and health condition (weight, height, body mass index, smoking and alcoholism) and was prepared by the investigator. This was followed by the Barthel scale, which evaluates the functional capacity of elders using scores from zero to 100.0 to assess the level of dependency in performing activities of daily living (ADLs). A score of 0-20 indicates total dependency; 21-66 severe dependency; $61-90$ moderate dependency; $91-99$ very little dependency; and 100 independency.

The last instrument to be applied was the Leisure Attitude Scale, originally devised in 1982 and validated in 2006, the only scale to measures the three attitude components separately. Formed by 36 items, 12 items to each component, it uses a five-level Likert scale. The value of the attitude measurements are obtained from the arithmetic sum of the responses given by the participant to each one of the items. The minimum score for each component is 12 and the maximum is 60 points, while neutral is 36 points. The minimum scale total is 36 points and the maximum, 180 points. It is important to highlight that values over 108 points reveal positive attitudes toward leisure and those below this value show a negative attitude. ${ }^{5}$

Descriptive analysis consisted of cross frequency tables, calculation of descriptive measures and attitude toward leisure, such as the mean and the standard deviation (SD). The associations between the categorical variables were verified by using Fisher's Exact Test. Spearman's correlation coefficient ( $r$ ) was used to verify the strength of the correlations between the different subscales of the leisure attitude scale.

The following hypotheses were adopted: 1 . No matter the sociodemographic and health conditions of the community-dwelling elderly, the overall attitude toward leisure activities is positive; 2 . The lack of public policies for senior citizens' leisure in Brazil make pleasant experiences difficult and have a negative impact on their attitude toward leisure.

A 95\% confidence level $(\alpha=0.05)$. was used to test the hypotheses. Data were analyzed using the Statistical Analysis Software (SAS, version 9.0) program using data from the Excel database.

The study was approved by the Research Ethics Committee for Human Beings of the Universidade Estadual de (COPEP/UEM), with opinion No. 615.612, in accordance with Resolution 466/12.

\section{RESULTS}

Regarding the sociodemographic profile of the elders who participated in the study, it was observed that the sample was predominantly formed by women (51.42\%), aged up 80 years old $(83.98 \%)$, with up to four years of education $(81.40 \%)$, living 
with a partner $(83.20 \%)$, retired $(95.52 \%)$ and with monthly income of up to four minimum wages $(95.61 \%)$. Regarding their health condition, wellnourished $(60.72 \%)$, non-smokers $(90.18 \%)$ or nonalcoholic (96.90), and independent (91.99\%) elders were prevalent in the study.

The results of the Leisure Attitude Scale analysis indicate an overall more positive attitude from the community-dwelling elderly in the three subscales, no matter their sociodemographic, health or functional capacity conditions. This shows that even senior citizens with inappropriate lifestyles have a more favorable attitude toward leisure activities.

No statistically significant differences were observed when the global leisure attitude scale was associated to sociodemographic characteristics such as age $(\mathrm{p}<1.000)$, sex $(\mathrm{p}<1.000)$, education $(0.123)$ or income (1.000) and health conditions such as smoking $(\mathrm{p}<1.000)$, alcoholism $(\mathrm{p}<1,000)$ and functional capacity $(p<0,101)$, as shown in Table 1.

Table 1 - Distribution of the sociodemographic and health condition variables according to the community-dwelling elders' global leisure attitude scale. Paraná, Brazil, 2014. (n=387)

\begin{tabular}{|c|c|c|c|c|}
\hline \multirow[b]{2}{*}{ Variables } & \multicolumn{2}{|c|}{ Attitude toward leisure } & \multirow[b]{2}{*}{$\begin{array}{c}\text { Total } \\
\mathbf{n}\end{array}$} & \multirow[b]{2}{*}{ p-value } \\
\hline & $\begin{array}{c}\text { Positive } \\
\text { n (\%) }\end{array}$ & $\begin{array}{c}\text { Negative } \\
\text { n (\%) }\end{array}$ & & \\
\hline \multicolumn{5}{|l|}{ Sex } \\
\hline Female & 195 (51.32) & $4(57.14)$ & 199 & \multirow{2}{*}{1.000} \\
\hline Male & $185(48.68)$ & $3(42.86)$ & 188 & \\
\hline \multicolumn{5}{|l|}{ Age group (years) } \\
\hline 60 ---- | 79 & 319 (83.95) & $6(85.71)$ & 325 & \multirow{2}{*}{1.000} \\
\hline $80 \mid---+$ & $61(16.05)$ & $1(14.29)$ & 62 & \\
\hline \multicolumn{5}{|l|}{ Education (years) } \\
\hline$\leq 4$ & $311(81.84)$ & $4(57.14)$ & 315 & \multirow{2}{*}{0.123} \\
\hline$>4$ & $69(18.16)$ & $3(42.86)$ & 72 & \\
\hline \multicolumn{5}{|l|}{ Marital status } \\
\hline Partner & 315 (82.89) & $7(100)$ & 322 & \multirow{2}{*}{0.607} \\
\hline No partner & 65 (17.11) & 0 & 65 & \\
\hline \multicolumn{5}{|l|}{ Occupation } \\
\hline Retired & $363(95.52)$ & $7(100)$ & 370 & \multirow{2}{*}{1.000} \\
\hline Paid work & $17(4.48)$ & 0 & 17 & \\
\hline \multicolumn{5}{|l|}{ Income (in wages)* } \\
\hline$\leq 4$ & $363(95.53)$ & $7(100)$ & 370 & \multirow{2}{*}{1.000} \\
\hline$>4$ & $17(3.63)$ & 0 & 17 & \\
\hline \multicolumn{5}{|l|}{ Body mass index } \\
\hline Well-nourished & $229(60.26)$ & $6(85.71)$ & 235 & \multirow{2}{*}{0.253} \\
\hline Overweight & $151(39.74)$ & $1(14.29)$ & 152 & \\
\hline \multicolumn{5}{|l|}{ Smoker } \\
\hline Yes & $38(10)$ & 0 & 38 & \multirow{2}{*}{1.000} \\
\hline No & $342(90)$ & $7(100)$ & 349 & \\
\hline \multicolumn{5}{|l|}{ Alcoholic } \\
\hline Yes & $12(3.16)$ & 0 & 12 & \multirow{2}{*}{1.000} \\
\hline No & 368 (96.84) & $7(100)$ & 375 & \\
\hline \multicolumn{5}{|l|}{ Functional capacity } \\
\hline Dependent & $29(7.63)$ & 2 (28.57) & 31 & \multirow{2}{*}{0.101} \\
\hline Independent & 351 (92.37) & $5(71.43)$ & 356 & \\
\hline
\end{tabular}

*Minimum wage amount: BRL 678.00 (USD 290.12). 
The senior citizens' attitudes toward leisure was positive both in the global scale $(98.19 \%)$ and in the subscale analysis: cognitive (99.22\%), affective $(97.42 \%)$ and behavioral (69.77\%). However, the behavioral subscale showed a different characteristic, with a smaller positivity percentage that allowed the identification of different standards toward leisure: two highly positive components and a discrete component.

Another important difference is in the mean scores reached in the subscales compared to the global scale (150 points), which shows a negative attitude toward leisure in each one of the evaluated components. The most important is the behavioral dimension (41 points) with the highest percentage of negative responses (Table 2).

Table 2 - Descriptive measures and attitudes toward leisure of the community-dwelling elderly. Paraná, Brazil, 2014. $(\mathrm{n}=387)$

\begin{tabular}{lccccc}
\hline Subscales & No. of items & Mean & SD $^{*}$ & $\begin{array}{c}\text { Positive }^{*} \\
\mathbf{n}(\%)\end{array}$ & $\begin{array}{c}\text { Negative }^{\dagger} \\
\mathbf{n}(\%)\end{array}$ \\
\hline Cognitive & 12 & 56 & 4.92 & $384(99.22)$ & $3(0.78)$ \\
Affective & 12 & 53 & 7.2 & $377(97.42)$ & $10(2.58)$ \\
Behavioral & 12 & 41 & 8.4 & $270(69.77)$ & $117(30.23)$ \\
Global & 36 & 150 & 5.52 & $380(98.19)$ & $7(1.81)$ \\
\hline
\end{tabular}

*SD: standard deviation; "Positive attitude toward leisure for each subscale and for the global scale; ${ }^{\dagger}$ Negative attitude toward leisure for each subscale and for the global scale.

There was no statistically significant association between the cognitive and affective components and attitude toward leisure. The behavioral component presented the smallest mean and was signifi- cantly associated with the age group $(\mathrm{p}<0.012)$, education $(\mathrm{p}<0.000)$, smoking $(\mathrm{p}<0,024)$ and functional capacity $(\mathrm{p}<0.026)$, as shown in Table 3.

Table 3 - Distribution of sociodemographic, behavioral and health condition characteristics according to the community-dwelling elders' attitudes toward leisure in the behavioral subscale. Paraná, Brazil, 2014. $(n=387)$

\begin{tabular}{|c|c|c|c|c|}
\hline \multirow[b]{2}{*}{ Variables } & \multicolumn{2}{|c|}{ Behavioral subscale } & \multirow[b]{2}{*}{$\begin{array}{c}\text { Total } \\
\mathbf{n}\end{array}$} & \multirow[b]{2}{*}{ p-value } \\
\hline & $\begin{array}{c}\text { Positive attitude } \\
\text { n (\%) }\end{array}$ & $\begin{array}{c}\text { Negative attitude } \\
\text { n (\%) }\end{array}$ & & \\
\hline \multicolumn{5}{|c|}{ Age group (years) } \\
\hline $60----\mid 80$ & 247 (86.97) & 78 (75.73) & 325 & \multirow{2}{*}{$0.012^{*}$} \\
\hline $80 \mid---+$ & $37(13.03)$ & $25(24.27)$ & 62 & \\
\hline \multicolumn{5}{|c|}{ Education (years) } \\
\hline$\leq 4$ & $220(77.46)$ & $95(92.23)$ & 315 & \multirow{2}{*}{$0.000^{*}$} \\
\hline$>4$ & $64(22.54)$ & $8(7.77)$ & 72 & \\
\hline \multicolumn{5}{|l|}{ Smoker } \\
\hline Yes & $20(7.41)$ & 18 (15.38) & 38 & \multirow{2}{*}{$0.024^{*}$} \\
\hline No & $250(92.59)$ & $99(84.62)$ & 349 & \\
\hline \multicolumn{5}{|c|}{ Functional capacity } \\
\hline Dependent & 16 (5.93) & 15 (12.82) & 31 & \multirow{2}{*}{$0.026^{*}$} \\
\hline Independent & 254 (94.07) & $102(87.18)$ & 356 & \\
\hline
\end{tabular}

*Significance level $\mathrm{p}<0.05$.

Table 3 shows that out of the 103 senior citizens who showed a negative attitude toward leisure in the behavioral subscale, $75.73 \%$ were aged up to 80 years old and $92.23 \%$ had been in the study for up to four years. It was also shown that among the elders who showed a negative attitude, $84.62 \%$ were non-smokers and $87.18 \%$ had preserved functional capacity, that is, they were not dependent for the activities of daily living. 
The correlation coefficients between the cognitive, affective and behavioral subscales, de- scribed in Table 4, showed statistically significant associations.

Table 4 - Correlation (Spearman) between the subscales (cognitive, affective and behavioral) of attitudes toward leisure for the community-dwelling elders. Paraná, Brazil, 2014. (n=387)

\begin{tabular}{lcc}
\hline Subscales & Correlation & p-value \\
\hline Cognitive versus affective & 0.63 & $0.0001^{*}$ \\
Cognitive versus behavioral & 0.26 & $0.0001^{*}$ \\
Affective versus behavioral & 0.44 & $0.0001^{*}$ \\
\hline
\end{tabular}

*significant at the 95\% confidence level.

It was observed that the correlations between the subscales were significant, showing that the three components are related to each other and ensure a consistent analysis of the different dimensions to obtain the attitudes toward leisure. The greatest correlation coefficient was between the cognitive and affective subscales $(r=0.63$; $\mathrm{p}=0.0001$ ), followed by the affective and behavioral correlation $(r=0.44 ; p=0.0001)$. The smallest coefficient was between the cognitive and behavioral subscales $(r=0.26 ; p=0.0001)$.

\section{DISCUSSION}

The prevalence of elderly women in research is a Brazilian reality. This was shown in a study performed with community-dwelling elderly in Porto Alegre-RS [Rio Grande do Sul]. This group was formed mostly by senior citizens aged up to 80 years old and women $(67.4 \%)$ and corroborates this study's findings. ${ }^{8}$ Women have a higher life expectancy, compared to men, featuring the feminization of old age, which results in greater involvement of this sex in older age groups. ${ }^{9}$

Given its complex approach, the definition of attitude and its measurement has been discussed in the psychosocial field. Contrary to common sense, attitudes are not measured by actions or behaviors but developed through a set of values that is accepted by the social environment. ${ }^{10}$ Beliefs, experiences and cognitive-social and/or emotional support act as a range of intermediate processes for the individual to be positive or negative toward a specific reality. ${ }^{11}$

They investigation of the senior citizens' attitudes toward leisure activities allows us to understand in which way leisure is structured in their lives and the importance given to this aspect.

Leisure activities such as participating in parlor games, watching TV, developing manual activities and maintaining a monthly relationship with friends are factors known to protect against the loss of functional capacity. They help the elderly to make the necessary adaptations to this stage of life. ${ }^{12-13}$ It is possible to improve their perception and attitude toward life and a positive attitude is therefore extremely important. A determining factor for involvement in leisure activities is one's attitudes toward it. ${ }^{5}$

In a general analysis, the community-dwelling elders' attitudes toward leisure activities were more positive. However, there was no significant association with the evaluated sociodemographic, behavioral or health condition characteristics, which shows that the attitude toward leisure in this population is not dependent on the components under investigation. The results found corroborate a study performed with teenagers and adults in Portugal, and obtained averages higher than the neutral point, which also characterizes positive attitudes toward leisure. $^{5}$

It can be said that in general individuals express positivity toward leisure activities and experiences. This finding indicates the significant importance of a positive attitude for a possible intervention through health promotion.

Adopting a more positive attitude toward leisure activities can benefit the elderly, particularly to better adapt to their incapacities and losses in old age. This is a strategy to face stress factors and the result is a sense of personal adjustment or positive psychological well-being. ${ }^{10}$ It is believed that having a positive attitude is associated to experiences that have permeated these community-dwelling elders' experiences and left feelings of well-being and satisfaction.

The analysis of attitudes according to the subscales showed representative differences in the affective and behavioral dimension, with the lowest 
means. This indicates a less positive attitude compared to the global scale. The cognitive subscale also had the highest mean while the behavioral subscale had the lowest mean in a study with Portuguese adolescents, youngsters and adults. This shows the differences between beliefs and the knowledge of leisure and its effective implementation into activities and behaviors in daily living. Therefore, the cognitive component is related to beliefs toward leisure. The affective component scales the intensity of the satisfaction one feels when involving oneself with leisure. The behavioral component is associated to prior actions and projections toward leisure activities. $^{5}$

Negative attitudes can be related to prior unsuccessful experiences or frustrated expectations of leisure projected for old age, which can be modified by adopting new behaviors. Senior citizens who had a negative attitude in the behavioral dimension can change their attitudes by experiencing more pleasant situations and building a new perception. All change leads to the deconstruction of pre-established concepts and gives rise to the formulation of new definitions. The adoption of new behaviors, feelings and actions toward leisure characterizes the multiple facets of attitude.

As they age, some people can experience a loss of autonomy that is negatively reflected in social coexistence, well-being and motivation and impacts their perception of the performance of leisure activities. ${ }^{10}$

Older people will potentially experiment a loss of functional capacity. This condition generates significant harm to the person's biological, social and psychological condition and affects the entire family. It can be associated to a greater risk of dependence, falls, hospitalization, institutionalization and death. ${ }^{14-15}$ Elders with severe incapacity demand the greatest care from the health services, particularly from the primary healthcare services, and generate more expenses with hospitalization and medication, in addition to suffering for the elder and his family. ${ }^{16}$ This is why activities that have the potential to be a protection factor to functional capacity must be stimulated and the associated factors must be monitored.

A study conducted in Minas Gerais with 107 elders registered with two Basic Health Units showed there is a positive relationship between high quality of life and the regular practice of physical leisure activities. The result is preserved mental health, greater cognitive capacity and good family functionality. ${ }^{17}$ However, leisure activities are not restricted to physical functions that require a certain degree of mobility; they are associated to intellectual, associative or artistic functions that can help one to adapt to a possible incapacity. ${ }^{14}$

Lack of information and motivation for leisure and low economic power make the elders insufficiently active in leisure and compromises their attitude. It is known that the socioeconomic status influences the practice of regular physical activities: people with greater purchasing power tend to be more physically active compared to those with less purchasing power. ${ }^{18-19}$

A majority of negative answers were obtained when the study population was asked about the acquisition of articles and equipment to use in their leisure activities. It can therefore be inferred that the low socioeconomic status associated to a few years of study contributes to less involvement, participation and stimulus for leisure activities, hence their negative attitude. ${ }^{20}$

A significant association between the three components was observed when the correlation between the subscales was investigated. The strongest relationship was between the affective and cognitive dimensions, with a different result from that found in the original scale and in the Portuguese version. In those studies, the greatest coefficient was found in the affective and behavioral subscales, indicating that the affective purpose is more influenced by what is known about the leisure activities than by what is perceived or experienced. ${ }^{5}$

These results indicate that the behavioral, affective and cognitive intentions are different from each other. More investigation on the contributions each one of the components has on the attitude shown by individuals is needed, especially pertaining to the behavioral domain, which presented the greatest negativity.

Once the senior citizens' attitude toward leisure activities is known, it is possible to guide them into a deep reflection through educational actions aimed at building new values regarding life and health, helping them to overcome the sociocultural, behavioral and functional barriers characteristic of this stage of life.

Participation in social leisure activities is always positive in rethinking values, feelings and attitudes. ${ }^{21}$ Greater involvement in educational 
actions, such as community and health groups, allows for great contributions to the life of the community-dwelling elderly, offering constructive, liberating, and pleasant experiences and changing their attitudes to quality of life, ageing and leisure. ${ }^{22}$

Leisure activities allow for independence, attribution of new feelings caused by self valuing, better involvement in social groups. They are especially important for women to have access to activities other than domestic work, allowing behavioral changes that benefit their biopsychosocial integrity. ${ }^{21}$ The significant relationship senior citizens have with their family, community and health professionals must be taken into consideration to achieve the critical factors for their health. This is the basis for a greater impact on the implementation of public policies specific to the elderly and on the reduction of incapacity and morbidity.

A study of 1,429 institutionalized elders in China had the objective of investigating the influence of leisure activities on functional capacity and depression. It confirmed that leisure activity performance generates positive impacts on the elders' functional capacity and psychological structure. ${ }^{23}$

The practice of pleasant activities by senior citizens has not received special attention due to several reasons: the healthcare professionals are unprepared, there are no public and social policies specific to this issue and the access to leisure is restricted by financial restrictions and architectural barriers for the elderly, who have movement restrictions and require help to get out of their homes. ${ }^{24}$ The different components of attitude toward leisure must be investigated in the contexts in which they are inserted, especially with regard to understanding leisure to establish associations, advance discussions and actions on the theme and to verify its impact on the senior citizens' health condition.

In this context, the nursing team must be aware of the implications of leisure to better quality of life. This is especially true of nurses who are in the frontline of Primary Healthcare, who must perform integrated health and education actions, and provide integral assistance for the individual's biopsychological needs. The understanding of health promotion the professionals have significantly influences their practice and the way they direct their actions. ${ }^{25}$ Prior to intervening, the multidisciplinary team must know the population's so- ciodemographic, cultural and health characteristics to verify the impact of determinants on the senior citizens' health condition and to prepare an effective intervention plan.

A strategy nurses can use to achieve collective health promotion is to form elderly groups (not for chronic conditions): groups are a creative, interactive and appropriate space to deal with several aspects of health promotion and to direct elderly healthcare to a more frequent practice of leisure activities..$^{25-26}$

Elderly people require special attention to their real needs. The healthcare professional will awaken the valuing of personal capacities with the goal of empowering the elderly for self-care, socialization and decision-making. This will be permeated by the adoption of a more positive attitude toward leisure and, consequently, toward health. ${ }^{6}$

\section{CONCLUSIONS}

The results show that the elderly have a positive attitude toward leisure. Nevertheless, the analysis of individual subscales revealed a positive attitude for the cognitive and affective components and a smaller percentage in the mean for the behavioral component. This reveals the need to act in a more structured manner to bring leisure to the community-dwelling elders' daily lives and to intervene in the way they react when they are involved in leisure activities

This approach contributes to strengthen the concepts, knowledge and public policies toward leisure. Stimulating new investigations on the behavioral dimension of attitudes toward leisure through the investigation of senior citizens' social, health and leisure in different contexts, such as ethnicity, age, social contexts and health practices will lead to the preparation of effective interventions for active ageing.

By performing this analysis of the elderly, this study was aimed at directing attention to their better involvement in leisure activities. The discussion of a topic that is still under development and that has presented potential for the education and health promotion of the elderly makes it possible to minimize functional and cognitive limitations caused by chronic disease complications, to stimulate independence and autonomy and to promote their well-being and satisfaction, which are extremely relevant in old age. 


\section{REFERENCES}

1. Dumazedier J. Lazer e cultura popular. $4^{\mathrm{a}}$ ed. São Paulo: Perspectiva; 2012.

2. Pavão ALB, Werneck GL, Campos MR. Autoavaliação do estado de saúde e a associação com fatores sociodemográficos, hábitos de vida e morbidade na população: um inquérito nacional. Cad Saúde Pública. 2013; 29(4):723-34.

3. Ferreira OGL, Maciel SC, Costa SMG, Silva AO, Moreira MASP. Active aging and its relationship to functional independence. Texto Contexto Enferm. 2012; 21(3):513-8.

4. Confortin SC, Giehl MWC, Antes DL, Schneider IJC, d'Orsi E. Autopercepção positiva de saúde em idosos: estudo populacional no Sul do Brasil. Cad Saúde Pública. 2015; 31(5):1049-60.

5. Freire $\mathrm{T}$, Fonte $\mathrm{C}$. Escala de atitudes face ao lazer em adolescentes e jovens adultos. Paidéia. 2007 Jan-Apr; 17(36):79-87.

6. Pereira LSM, Soares SM. Fatores que influenciam a qualidade de vida do cuidador familiar do idoso com demência. Ciênc Saúde Coletiva. 2015; 20(12):3839-51.

7. Lucumí DI, Grogan-Kaylor A, Espinosa-García G. Asociación de la posición socioeconómica y la percepcióndel ambiente com la autopercepción del estado de salud em mujeres de Bogotá, Colombia. Rev Panam Salud Pública. 2013; 34(1):14-20.

8. Vitorino LM, Paskulin LMG, Vianna LAC. Quality of life of seniors living in the community and in long term care facilities: a comparative study. Rev LatinoAm Enferm. 2013 Jan-Fev; 21(Spec): 3-11.

9. Camargos MCS, Gonzaga MR. Viver mais e melhor? Estimativas de expectativa de vida saudável para a população brasileira. Cad Saúde Pública. 2015; 31(7):1460-72.

10. Silva LCC, Farias LMB, Oliveira TS, Rabelo DF. Atitude de idosos em relação à velhice e bem-estar psicológico. Rev Kairós Gerontol. 2012 Jun; 15(3):11940.

11. Castro VC, Carreira L. Atividades de lazer e atitude de idosos institucionalizados: subsídios para a prática de enfermagem. Rev Latino-Am Enfermagem. 2015; 23(2):307-14.

12. Rocha SV, Almeida MMG, Araújo TM, Santos LB, Rodrigues WKM. Fatores associados à atividade física insuficiente no lazer entre idosos. Rev Bras Med Esporte. 2013; 19(3):191-5.

13. Fernández-Mayoralas G, Rojo-Pérez F, MartínezMartín P, Prieto-Flores ME, Rodríguez-Blázquez C, Martín-García S, et al. Active ageing and quality of life: factors associated with participation in leisure activities among institutionalized older adults, with and without dementia. Ageing Ment Health. 2015; 19(11):1031-41.

14. Morley JE, Vellas B, Van Kan GA, Anker SD, Bauer JM, Bernabei R, et al. Frailty consensus: a call to action. J Am Med Dir Assoc. 2013 Jun; 14(6):392-7.

15. Maselko J, Sebranek M, Mun MH, Perera B, Ahs J, Ostbye T. Contribution of generative leisure activities to cognitive function in elderly Sri Lankan adults. J Am Geriatr Soc. 2014 Sep;62(9):1707-13.

16. Fialho CB, Lima-Costa MF, Giacomin KC, Loyola Filho AI de. Capacidade funcional e uso de serviços de saúde por idosos da região metropolitana de Belo Horizonte, Minas Gerais, Brasil: um estudo de base populacional. Cad Saúde Pública. 2014; 30(3):599-610.

17. Campos ACV, Cordeiro EC, RezendeGP, Vargas AMD, Ferreira EF. Quality of life of elderly practitioners of physical activity in the context of the family health strategy. Texto Contexto Enferm [Internet]. 2014 [cited 2016 Fev 05]; Out-Dez; 23(4):889-97. Available from: http:/ / www.scielo.br/scielo.php?script=sci_ arttext\&pid=S0104-07072014000400889

18. Focchesatto A, Rockett FC, Perry IDS. Fatores de risco e proteção para o desenvolvimento de doenças crônicas em população idosa rural do Rio Grande do Sul. Rev Bras Geriatr Gerontol. 2015; 18(4): 779-95.

19. Dias DF, Loch MR, Ronque ERV. Barreiras percebidas à prática de atividades físicas no lazer e fatores associados em adolescentes. Ciênc Saúde Coletiva. 2015; 20(11):3339-50.

20. Ferreira CL, Santos LMO, Maia EMC. Resiliência em idosos atendidos na Rede de Atenção Básica de Saúde em município do Nordeste brasileiro. Rev Esc Enferm USP [Internet]. 2012 [cited 2016 Fev 05]; 46(2):328-34. Available from: http://www.scielo.br/pdf/reeusp/ v46n2/a09v46n2.pdf

21. Baldissera VDA, Bueno SMV. O lazer e a saúde mental das pessoas hipertensas: convergência na educação para a saúde. Rev Esc Enferm USP [Internet]. 2012 [cited 2015 Mai 28]; 46(2):380-7. Available from: http://www.scielo.br/pdf/reeusp/v46n2/a16v46n2. pdf

22. Patrocinio WP, Pereira BPC. Efeitos da educação em saúde sobre atitudes de idosos e sua contribuição para a educação gerontológica. Trab Educ Saúde. 2013 Mai-Ago; 11(2):375-94.

23. Zheng O, Alice MLC, Ting KN, Liu S. Leisure, functional disability and depression among older Chinese living in residential care homes. Ageing Ment Health. 2015; 19(8):723-30..

24. Firmino BST, Mesquita LA, Costa SSM, Lima CCM, Carvalho FAF, Santos AMD. Promoção da saúde: a qualidade de vida nas práticas da enfermagem. Enferm Global. 2013 Out; 12(32): 260-9. 
25. Janini JP, Bessler D, Vargas AB. Educação em saúde e promoção da saúde: impacto na qualidade de vida do idoso. Saúde debate [Internet]. 2015 [cited 2016 Mar 09]; 39(105):480-90. Available from: http:// www.scielo.br/pdf/sdeb/v39n105/0103-1104- sdeb-39-105-00480.pdf

26. Pilger C, Dias JF, Kanawava C, Baratieri T, Carreira L. Compreensão sobre o envelhecimento e ações desenvolvidas pelo enfermeiro na atenção primária à saúde. Cienc Enferm. 2013; 19(1):61-73. 